\title{
THE CORRELATION BETWEEN SPATIAL PLANNING AND SUSTAINABLE TOURISM DEVELOPMENT: CASE STUDY OF BOSNIA AND HERZEGOVINA
}

\author{
Amina Sivac ${ }^{1}$ \\ Aida Korjenić ${ }^{2}$ \\ ŠevkijaOkerić $^{3}$ \\ Amra Banda ${ }^{4}$
}

\begin{abstract}
Spatial planning is an important concept for identifying the benefits of the tourism for tourist destinations, but also for environment and local communities. Even though that spatial planning and tourism are often perceived as two separate concepts, they are in fact, greatly interrelated. Natural resources, social infrastructure, population and its activities form the basis of spatial planning so they are inseparable from tourism. Tourism infrastructure and activities take place in a certain localities, so they have a spatial character, therefore tourism planning must be integrated in the spatial planning process at all levels. On the other hand, tourism is often perceived as a primary income generator for the members of local community in many countries, including Bosnia and Herzegovina in the last few years. Thispaperanalyzes the role and importance of spatial planning for the development of sustainable tourism concept. Bosnian legislation system regarding spatial planning and tourism should be improved in general, but especially in terms of sustainability. For this reason, a model for sustainable tourism development in Bosnia and Herzegovinais proposed. The aim of the article is to determine how to integrate spatial planning to sustainable tourism development and to decide the possible pathways within sustainable tourism development. The model considers all levels, from national to local. This model could be used to deal with all aspects of planning, such as policies, strategies, spatial decisions, building structuring, density, tourist site planning and design of tourists' objects and infrastructure.
\end{abstract}

Key words: spatial planning, tourism planning, sustainable development, tourism,Bosnia and Herzegovina

\section{INTRODUCTION}

Tourism, as a modern form of escapism and a unique phenomenon of our time, has increased to unpredictable development levels. However, in recent period of time, notably current and previous year, tourism industry has faced some serious problems, due to the increasing number of terrorist attacks and political issues worldwide.

\footnotetext{
${ }^{1}$ Teaching Assistant, Department of Geography, Faculty of Science, University of Sarajevo, Zmaja od Bosne 33 - 35, 71000 Sarajevo, amina.sivac@pmf.unsa.ba

${ }^{2}$ Assistant professor, Department of Geography, Faculty of Science, University of Sarajevo, Zmaja od Bosne 33 - 35, 71000 Sarajevo

${ }^{3}$ Assistant professor, Department of Geography, Faculty of Science, University of Sarajevo, Zmaja od Bosne 33 - 35, 71000 Sarajevo

${ }^{4}$ Senior Teaching Assistant, Department of Geography, Faculty of Science, University of Sarajevo, Zmaja od Bosne 33 - 35, 71000 Sarajevo
} 
Consequently, this industry has faced various pressures in terms of the variations of consumer demands and various economic turbulences. On the other hand, a number of world tourist destinations faced an additional problem, relating to their unplanned and uncontrolled development.These events encouraged governments to realize that tourism development needs tobe planned in accordance with other economic sectors, taking into account global trends, but also with a particular regard to the space in which it develops. The recognition of tourism as a part of the space and identification of correlation between the spatial and tourism planning have the particular importance in the recent period, and therefore this correlation will be the subject of this paper.

Without a doubt, tourism can contribute to socio-economic development or reconstruction of certain areas, but without certain instruments (such as spatial plans, spatial plans of special purpose, urban plans etc.), it is difficult to achieve the targeted development plans. Tourism can transform the regions in every sense, so it must be linked to spatial planning. Given the growing economic activity, tourism is assumed to continue to increase the demand for space. This is especially important if we take into account the fact that the space is limited and it cannot berelocated from one location to another (Marinović - Uzelac, 2001).

Therefore, the need for a systematic and interdisciplinary spatial planning of tourism at different levels: local, regional, national and international has emerged. A practical experience has shown that the planning of tourism without connecting to other sectors can cause long-term negative consequences in space, and thus society. Today, the negative effects of tourism in the territory of Bosnia and Herzegovina can be expressed through an illegal construction of touristic infrastructure in protected nature areas, abandoned historical monuments and winter sports infrastructure, insufficient quality of drinking water due to the excessive construction, poor transport infrastructure, lack of parking lots, devastation of cultural and natural resources, and so on. In consideration of the negative effects of tourism in the area, an interdisciplinary spatial and tourism planning approach should be implemented.

The situation in Bosnia and Herzegovina is, unfortunately, such that the spatial plans are often perceived as an instrument for adjustment of land use for investors, and the essence of spatial planning as anoptimal allocation of people, goods and activities in the area is often ignored. The fact that spatial planning is closely related to the law, economics, cultural goods, ecology, transport, etc. is commonly overlooked. Although the relationship between space and tourism is very complex, it is very important to reflect on the impact of spatial planning on the development of tourism at national, regional and local level, in order to contribute to sustainable development of society of Bosnia and Herzegovina. An increased number of the tourist visits, as well as the increase of the number and size of tourist accommodation facilities, or in other words the growth of the overall tourism industry in Bosnia and Herzegovina should generate enormous effects on the economy.

However, this is unfortunately not the case, because of the fact that the uncontrolled and unplanned tourism development favors the development of the informal economy. 
On the other hand, increased number of tourists affects the cultural identity, as well as the physical surrounding and environment. On a national level, this requires an adequate approach to tourism planning process.

\section{CONCEPTUAL DEFINITION AND CORRELATION OF SPATIAL PLANNING AND TOURISM}

Spatial planning aims to ensure the adequate location of activities, a balanced social and economic development and the enhancement of the landscape.It is an essential responsibility of the state and it should be carried out with citizen participation, in a framework of sustainable development. Spatial planning is, basically, the management of the natural interaction between man and space and it is essentially used to correct the effect of human and economic, and therefore, touristic activities. Planners dealwith many subjects related with land use, as the development of transportation and infrastructure, the protection of natural and cultural resources, habitats and environment, the conversion of natural to urban built areas, the planning of social services and equipment, etc. Thus, it can be stated that spatial planning is an important part of social and economic policy, which aims to ensure that the land is used efficiently and that is why it has contributions from many disciplines like urban planning, geography, tourism or architecture, among others.

There are numerous definitions of spatial planning. The European Regional/Spatial Planning Charter (1983) gave one of the earliest spatial planning definitions: "Regional/spatial planning gives geographical expression to the economic, social, cultural and ecological policies of society. It is at the same time a scientific discipline, an administrative technique and a policy developed as an interdisciplinary and comprehensive approach directed towards a balanced regional development and the physical organization of space according to an overall strategy." According to this document, spatial planning should always try to maintain a long-term oriented, functional, comprehensive and democratic characteristic. Furthermore, it aims to achieve responsible management of natural resources and protection of the environment, balanced socio-economic development of the regions; rational use of land and improvement of the quality of life in general. In 1970, the Council of Europe held the first European Conference of Ministers responsible for Regional Planning (CEMAT) in Bonn. Ever since, the EU developed a set of important initiatives for the Spatial Planning and some fundamental documents. The signature of the European Regional/Spatial Planning Charter, adopted in 1983 at the 6th Session of the CEMAT in Torremolinos was one of the earliest initiatives but there were others of the same importance, like the implementation of European Spatial Development Perspective (ESDP), in 1999; The Guiding Principles for Sustainable Spatial Development of the European Continent, adopted at the 12th Session of the CEMAT, held in Hanover in 2000; the establishment of the ESPON Programme2006 (European Spatial Planning Observatory Network Program 2006); and the Territorial Agenda for the European 
Union, in 2007. All these initiatives have guided spatial planning policies in Europe.One of the main goals of the spatial planning process is to create the conditions for an enhanced quality of life, through public participation and to meet the challenges of sustainable development in general, therefore sustainable development in tourism sector as well. Spatial planning is used to ensure that the utilization of land resources is planned and implemented in an organized in such way that it meets the needs of present but also of the future generation. This type of planning requires an integrative and comprehensive approach in order to rationalize the appropriate land use activities.Spatial plans are used to assess applications submitted by property developers. They also guide changes in land-use rights and guide public investment in infrastructure. However, they do not give or take away land use rights. The implementation of these plans relies on partnerships between the private sector, communities and other spheres of government. Spatial planning can also be described as the activity which generates an integration of social, environmental, cultural and economic interest in order to develop an attractive, sustainable and functional environment, which is especially important for an adequate tourism development process. Hence this type of planning focuses on the relationships between people and space and understanding of the environmental, cultural, social and economic interrelations at all the planning levels - from local to national.

Since tourism is a complicated activity that covers various sectors of economy and a dynamic social interaction process, it is argued that unexpected and adverse impacts related to the tourism sector may come into existence in the absence of any planning effort. The tourism sector is related to shops, restaurants, transportation networks and accommodation, all of which are included and defined within urban planning (Dredge \& Moore, 1992). Urban planning is a public sector activity for the benefits of communities. While tourism industry is heavily based on private sector entrepreneurship, spatial planning is an intervention mechanism for the evolution and development of tourism for the public and environmental benefit. The role of spatial planning in tourism at local level is related mostly to the supply side of tourism. In this sense, it is compulsory to understand tourism systems. Gunn's model (1988) might be helpful in representing various elements of tourism at demand and supply side. There are dynamic relations between demand and supply sides in Gunn's model. The demand side consists of population and number of tourists whereas the supply side contains resources for tourism as attractions, variety of tourism services and transportation (Gunn, 1988). It is clear that the elements of the supply side are core issues of urban planning. Spatial planning can be used as a tool for organizing supply side elements of tourism. Planners make direct and indirect decisions about land use, quality of services and accessibility (Dredge \& Moore, 1992). The role of planning in the tourism sector differs according to various levels. At the level of national strategic plans, a vision for the desired tourism development can be set out whereas in physical plans, such as city or town plans, concrete and tangible decisions are made concerning the structure of tourism sector in a locality. The links between tourism infrastructure and services are 
also presented in these types of plans, which are of vital importance for the efficiency of the tourism sector and future of a locality.

From the perspective of tourism development the most important issues in spatial planning are: location of tourism facilities, accessibility issues, standard definitions, design standards, traffic problems, quality of built environment, tourism attractions, location of major transport interchanges, impacts of tourism development on local architectural styles and important heritage sites (UN, 1999). In particular, spatial planning is the most critical step in the process of sustainable tourism development. It is previously stated that, in general, the benefits of spatial planning are economic, social and environmental. Out of these, the benefits of spatial planning for the development of sustainable tourism could be defined as economic benefits through ensuring environmental quality to create favorable conditions for investment while trying to satisfy needs of local communities; social benefits through considering needs of local communities, supporting the provision of local infrastructure and superstructure, maintaining healthy and safe environments and environmental benefits through promoting regeneration and appropriate use of land and buildings, conserving natural, historical and cultural assets, protecting natural structures, encouraging energy saving and energy efficiency (UN, 2008). Spatial planning could be considered a buffer mechanism between the private sector and the public for the benefits of all the stakeholders. Touristic development mostly depends on natural, historical and cultural assets and their continuity. Representing the interest of public stakeholders, planning institutions are the most important stakeholders guarding continuity of these assets with correct, pluralistic and democratic decisions. It is stated that: "Sustainable development is the core principle under planning. At the heart of sustainable development is the idea of ensuring a better quality of life for everybody now and for further generations. The planning process provides the opportunity to help to make new developments more sustainable" (U.K. Department for Communities and Local Government, 2009). A way to achieve sustainable tourism development is related to correct and consistent decision making on land use at local levels. The role of spatial planning is important for the tourism sector in order to "maximize positive benefits of tourism and minimize negative impacts in a sustainable manner" (UNEP, 2009).In general, spatial planning in tourism can be divided into categories of national and transnational planning, regional planning and local or urban planning. National plans are at the top of this hierarchy as decisions at sub-stages depend on national planning within a top-down planning approach. The national and regional levels are related more to policy levels whereas urban planning and urban design are related more to space and spatial issues within tourism destination development. Spatial planning, therefore, plays an important role in the development of the tourism sector as is the case for many other sectors. It is compulsory to understand the importance of planning within the tourism sector. As tourism is a complicated activity that covers various sectors of economy and a dynamic social interaction process it is argued that unexpected and adverse impacts related to the tourism sector may come into existence in the absence of any planning effort. The role of planning in the tourism 
sector differs according to various levels. At the level of national strategic plans, a vision for the desired tourism development can be set out whereas in physical plans, such as city or town plans. From the perspective of tourism development the most important issues in spatial planning are:

- location of tourism facilities,

- accessibility issues,

- design standards,

- traffic problems,

- quality of built environment,

- tourism attractions,

- location of major transport interchanges,

- impacts of tourism development on local architectural styles and important heritage sites (UN, 1999).

In particular, spatial planning is the most critical step in the process of sustainable tourism development. It was mentioned that, in general, the benefits of spatial planning are economic, social and environmental. Out of these, the benefits of spatial planning for the development of sustainable tourism could be defined as economic benefits through ensuring environmental quality to create favorable conditions for investment while trying to satisfy needs of local communities; social benefits by considering needs of local communities, supporting the provision of local infrastructure and superstructure, maintaining healthy and safe environments and environmental benefits of promoting regeneration and appropriate use of land and buildings, conserving natural, historical and cultural assets, protecting natural structures, encouraging energy saving and energy efficiency (UN, 2008). Spatial planning could be considered a buffer zone between the private sector and the public for the benefits of all the stakeholders. In tourism, its development mostly depends on natural, historical and cultural assets and the continuity of these assets.

\section{TOURISM PLANNING AND SUSTAINABLE TOURISM DEVELOPMENT}

The process of sustainable development in tourism is closely linked with the principles of environmental protection, and as such includes a spectrum of different research activities and studious analysis of geo-ecological processes, as well as an analysis of nature laws and regularities in specific areas.Attitudes towards the concept of sustainability in tourism vary and according to some authors, this concept identifies with the process of intensification of tourist activities in the area, while other authors have diametrically opposed opinions and understand this concept as an alternative tourism and they strongly oppose to the development of mass tourism. According to Hunter (1997), it is extremely difficult to imagine the formulation and implementation of any approach to sustainable tourism in the absence of strong local (including regional) authority planning and development control, and without the involvement of 
local communities in the planning process to some degree. Tourism planning is a key solution for several problems which may occurin the management of tourism resources. It includes the identification and evaluation of tourism resources, with increased revenues and reduced costs and with respect to a holistic attitude towards the environment. Hall (2008) considers that it is necessary to define the roles and relationships of various control mechanisms for the operation of all levels included in the process of tourism planning, from local to national. This control system involves the inclusion of local communities in the decision-making process. Local community is the first link in the complexed tourism planning process, and therefore it is very important to take into account the views of the residential population. All stakeholders' interests need to be reconciled, and the cooperation among them is necessary in order of successful planning process. Planning and plan the different categories, and in this regard must be considered separately. Tourism planning is a continuous process, it is a dynamic category, as opposed to the plan, which is a static category and is a vision of a future state. This process is not a scientific discipline, but a social practice which is based on an analysis of the situation, defining the methods by which they want to achieve certain goals, and at the end of the synthesis of existing knowledge.

According to Perišić (1985), planning is a social practice based on the analysis, knowledge, method and synthesis. It represents a process of preparing a set of decisions on actions in the future, which is aimed at achieving the objectives of the preferred means. The goals of tourism planning are supposed to be consistent with the general development goals of the society, and therefore they should result in the harmonization of conflict of interest. The plan, on the other hand is one of the instruments in the process of tourism planning. One of the main goals of tourism planning is to achieve the desirable quality of life, measured in relation to the level of satisfying the needs and interests of the local community, destination managers and the environment. The objectives must also reflect the public interest and individual interests, where the individual interests must simultaneously fit the general public interest and vice versa. Tourism planning is expected to contribute to the articulation of individual, group, collective and sectoral interests, needs, desires and preferences; to enable their confrontation and rapprochement and relativization through dialogue and negotiation. Five basic approaches to tourism planningcan be identified:

1) Boosterism - Fast development of mass tourism

2) Economic, industry-oriented approach

3) Physical / spatial approach

4) Approach oriented to the local community

5) Sustainable tourism development approach.

Boosterism is the dominant tourism planning approach in a large number of developing countries. It is often confused with mass tourism. The biggest drawback of this approach is that very little attention is paid to the capacity of the space, because despite the fact that it has positive effects on the country's economy in a short period of time, it often results in environmental degradation. Therefore, tourism is destroying the area in 
which it develops.An economic approachis characterized by a strong incentive of state and government for the development of tourism. This approach is also primarily oriented to making a profit from tourism. However, it is characterized by somewhat greater appreciation of the environment and the local community than is the case with boosterism, but not to a satisfactory degree.Physical/spatial approach is presented in the works of geographers and spatial planners who strongly emphasize the importance of environmental protection in the planning process. Attention is given to physical planning, zoning activities, as well as the environmental impacts of tourism in the subject area, while the issues of socio-cultural effects are practically disregarded.Access oriented to the local community is based on the ideology that satisfying the needs of tourists is possible while satisfying the needs of the residential population. This approach aims at providing the backbone for raising living standards of the local population through economic benefits arising from tourism; the development of infrastructure that is used by both - tourists and residential population; providing tourist facilities that are consistent with the natural characteristics of the area and so on.Although "bottom up" approach allows the local community and local players to express their views and to help define the development course for their area in line with their own views, expectations and plans, it cannot be applied (nor is it applicable) systematically to all places in all circumstances. However, a participatory process takes longer, because a diverse group always takes longer to make decisions and come to conclusions than does an individual or small group. Members of the target population may need new skills in order to participate fully in the planning process. Spatial planners, on the other hand, may need to learn more about local culture, political issues, and community history in order to adequately implement the process of tourism planning. It also may be difficult to assure that all the right people get to the table. Some key persons simply may not want to participate in tourism planning process. This approach takes patience and commitment on everyone's part, so it is somewhat more complex to implement, but it is still one of the best approaches to tourism planning. The primary objective of a sustainable approach to tourism planning is to ensure long-term survival of the destination while minimizing resource depletion and environmental degradation. Raising awareness of consumers and service providers refers to the global growth trend of environmental awareness, which is an imperative in tourism planning. The important role given to the spatial planning in the process of achieving environmental and economic sustainability is evident in many official policy documents and debates worldwide. The crucial role of spatial planning in sustainable development and improvement of the quality of live is also underscored by the UN (2008), where it is stated that ,spatial planning achieves its social, economic and environmental aims by securing community benefits from development by promoting prudent use of land and natural sources for development". 


\section{SPATIAL PLANNING IN BOSNIA AND HERZEGOVINA AND ITS EFFECTS ON TOURISM DEVELOPMENT}

Spatial planning in Bosnia and Herzegovina has been regulated by the legislation on the basis of socialist development until 1992. The three last acts in this period and this area as well as the additional provisions, together with the relevant methodology of preparation of spatial planning documents, were adopted in 1987 and are now invalid. In the new Constitution of Bosnia and Herzegovina, theStrategy of spatial planning does not exist at the state level.

The consequence of this is the fact that such a significant issue is not regulated by the law. Each entity by itself, without mutual coordination, is planning and running the most important interventions in the area. Only national strategy can ensure better planning and implementation of the primary transport and energy corridors, defining the spatial coverage and categorization of protected areas, cultural and historical heritage and other issues of interest to the state. However, it must be secured unique access and adequate methodology making strategic goals. The absence of any form of administrative management of the area and the lack of a national strategy spatial planning may jeopardize the proper regional development.

Table 1. Competence in the framework of spatial planning in Bosnia and Herzegovina

\begin{tabular}{|c|c|c|}
\hline \multicolumn{3}{|c|}{ BOSNIA AND HERZEGOVINA } \\
\hline $\begin{array}{c}\text { The Federation of Bosnia and } \\
\text { Herzegovina }\end{array}$ & $\begin{array}{c}\text { The Republic of } \\
\text { Srpska }\end{array}$ & Brčko District \\
\hline $\begin{array}{c}\text { Entity level: } \\
\text { Law on spatial planning and } \\
\text { land use at the Federation of } \\
\text { BiH (FBiH Official Gazette } \\
\text { 06/02) and amendments in } \\
\text { 2007, 2008, and three } \\
\text { changesin } 2010 .\end{array}$ & \multirow{2}{*}{$\begin{array}{c}\text { Entity level: } \\
\text { Law on Spatial } \\
\text { Planning and } \\
\text { Construction in the } \\
\text { Republic of Srpska } \\
\text { (Official Gazette no. } \\
55 / 10)\end{array}$} & \multirow{3}{*}{$\begin{array}{c}\text { Law on Spatial } \\
\text { Planning } \\
\text { and Construction } \\
\text { (Official Gazette o } \\
\text { the Brčko District, } \\
\text { no. 29/08) }\end{array}$} \\
\hline $\begin{array}{c}\text { Cantonal level: } \\
\text { Each of the } 10 \text { cantons has its } \\
\text { own law on spatial planning }\end{array}$ & & \\
\hline $\begin{array}{c}\text { The municipal level: } \\
\text { Decision on spatial planning } \\
\text { specific to each municipality }\end{array}$ & $\begin{array}{l}\text { The municipal level: } \\
\text { Decision on spatial } \\
\text { planning specific to } \\
\text { each municipality }\end{array}$ & \\
\hline
\end{tabular}

The need for an adequate spatial and tourism planning of Bosnia and Herzegovinais caused by certain imbalances in economic and social development, which are most evident in the post-war period. These imbalances resulted in forms of different current processes occurring in this area, such as: 
- Uncontrolled use of resources, illegal land management, unplanned development and deployment of industry and other activities extra-urban areas;

- The regional disparity in terms of level of development, due to the lack of integration and planning instruments in managing and directing the development of Bosnia and Herzegovina;

- Excessive and uncontrolled growing of the capital city, primarily as a result of population displacement due to the last war, which resulted in unfavorable conditions of life in the neglected, communal unequipped and traffic congested urban space and peri-urban areas;

- Depopulation of some rural areas, also as a result of population displacement due to the last war and due to the intensive urbanization process;

- Loss of cultural values and traditional patterns of behavior and others.

An integrated approach to tourism planning of Bosnia and Herzegovina implied to integrate the objectives of tourism development for the universal goals of improving the quality of life and environmental quality in this area. The pursuit of such an approach is increasingly present in all European countries and the developed planning systems. The use of this form of tourism planning of Bosnia includes a multitude of assumptions (geographical, economic, political, etc.). Moreover, some of the main conflicts in spatial planning in both entities appear in tourism sector. These conflicts could be summarized through institutional conflicts in the plans' approval process and inefficiency of planning manifested in lack of capability to conserve natural and cultural resources. Therefore, improvement in spatial planning should be devised in suchway to ameliorate these problems.

Fig. 1: The level of planning, types of plans and relations between plans in Federation of Bosnia and Herzegovina

\section{Spatial plan of Federation of Bosnia and Herzegovina}

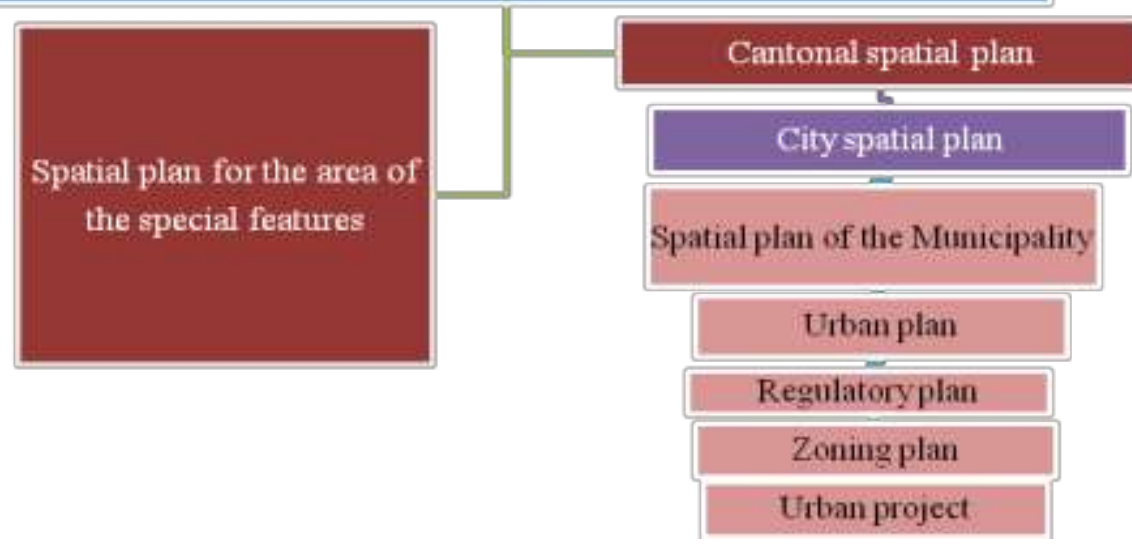




\section{A PROPOSED SPATIAL PLANNING MODEL FOR THE PLANNING OF TOURISM IN BOSNIA AND HERZEGOVINA}

The lack of a national spatial plan and the identification of numerous problems related to spatial planning resulted in our creation of spatial planning model for tourism development at multiple levels in Bosnia and Herzegovina. The aim was to propose ways in which the process of sustainable tourism planning can be integrated in the potential and actual spatial plans in this area.

The proposed model consists of two parts - the operation chart and the institutional and legal aspects that support the planning process. After explaining the model, some information on the institutional structure will be given to clarify the roles of the most important stakeholders in tourism development in Bosnia and Herzegovina.A top-down approach is important for ensuring sustainability as it offers a holistic approach for problem solutions in the context of sustainable tourism development. The structure of the model depends on the feedbacks at each planning level related to the sustainability criteria. All planning levels have their own sustainability criteria and these necessitate feedbacks at every stage/level.

The feedbacks related to the sustainability criteria constitute the most important part of the model presented in Figure 2. The first level is mostlyrelated to national policies, strategies and decisions and international agreements relevant to the tourism sector. This level is a policy rather than a spatial planning level. Some factors that could be helpful for determining the national tourism strategies are research on regional potentials, legal administrative processes of the country and international agreements that affect the decision making process. The national development plans, tourism strategy documents, national and international tourism agreements become the main determinants of future development of the tourism sector.

Fig. 2: The proposed spatial planning model for tourism development of Bosnia and Herzegovina at National level

\section{National Spatial Plan or Entity plans and Policy}

\section{Basic strategies}

Research on regional touristic potentials

Definition of touristic regions and destinations
Sustainability criteria:

Environmental, cultural and socio- cconomic sustainability, achieved by the following

Maximising social, economic benefits to local communitics, minimising negative effects Maximising benefits to cultural heritage

Maximising benefits to environment, minimising negative effects 
Cantonal and City Spatial Plans at sub-regional and regional levels are the focus of the second stage, where regional economic relations are standing out in terms of employment opportunities. Besides, the decision on terms of evaluation of naturalgeographical and cultural-historical attributes of a destination is made at this stage. The sustainability criteria at this level includes the conservation of natural and cultural heritage, improvement of public transport, improved local economy and employment opportunities, implementation of standards related to the infrastructure etc.

It is very important to emphasize the importance of carrying capacities, which need to be considered in the process of setting sustainable tourism goals. In this respect, the definition of regional carrying capacities is a vital factor. This is determined by the mutual interaction of local residents and tourists. Carrying capacity is a complex issue and has various dimensions such as physical, ecological, demographic, political and economic.Cantonal and City Spatial Plans (Scale 1:100.000 and 1:50.000) should be prepared or revised taking into consideration these sustainability criteria. In order to realize this step, the potentials of the region and appropriated databases should be established.

Fig. 3: The proposed spatial planning model for tourism development of Bosnia and Herzegovina at Cantonal/City level

Cantonal and City Spatial Plans

\section{(Scale 1:100.000 and 1:50.000)}

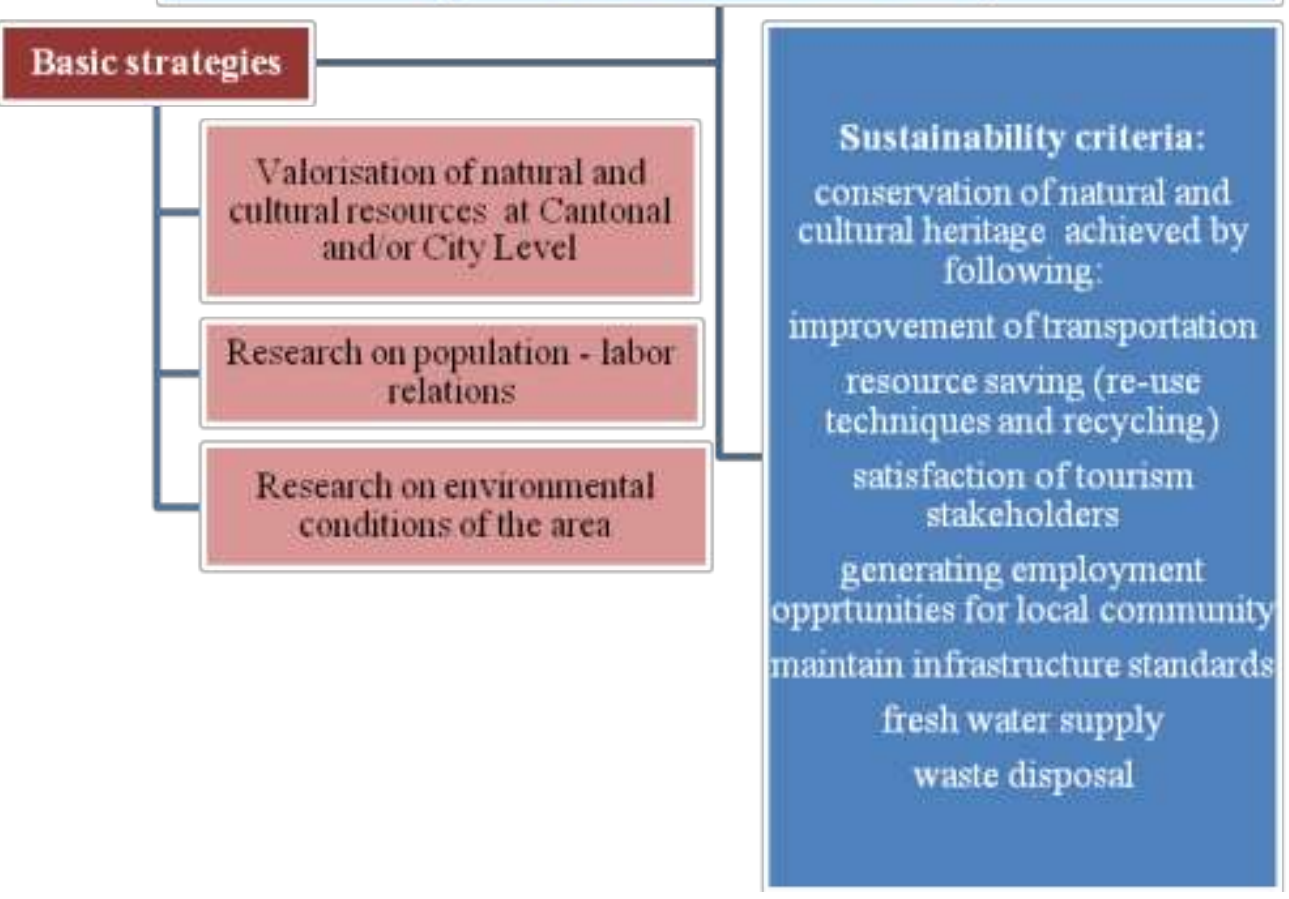


The third stage is oriented towards the urban planning. The map scales at this level are 1:5000 and 1:1000. The decisions at this stage consist of land use, transportation, selection of tourism activities, location choice for tourist facilities etc. The plans are divided into two categories: "master" plans and implementation plans, where the first ones are done at the scale of 1:5000 and are used to display locations and relations of tourism zones within an urban area, while implementation plans, which are done at the scale of 1:1000, display the relationship of the area with its environment. "Master" plans are also used for making some basic decisions, such as land use, basic energy inputs, types of transportation andchoice of location for some facilities, whereas other decisions are made in implementation plans, such as transportation connections, definition of standard public areas (recreation, health etc.) at the scale of 1:1000.

This stage is also oriented at defining the authority and stakeholders, notably members of the local community, which opinion must be considered in the process of further touristic valorization. Members of the local community can actively participate in the process, as providers of services of accommodation or as local tour guides and other. This is especially important if we take into account that members of the local community expect to benefit from tourism, so considering local authorities as the decision makers and supporters of the plans would be desirable. However in further process, an implementation of the decisions should be left to professionals and informing the public about these decisions would ensure a participative planning process. Participative planning is critical for the success of these plans because tourism is an interactive and dynamic process and ideas of local people as well as decision makers become crucial factor for success of sustainable tourism development.

Some of the sustainability criteria at this stage are: minimizing contamination and noise pollution, protecting natural-geographical and cultural-historicalresources, forming public spaces and open areas while applying recycling and re-using technologies, improving living conditions of the local community, achieving accessibility through interaction with nearby settlements and similar. The main issue of the fourth is the site planning, which deals with architecture. An important part of this stage is a design of the accommodation and service facilities. Itis of crucial importance that new buildings are constructed from local materials and in accordance with the natural geographic conditions of the area. It is important to emphasize that the existing facilities should be adapted and renovated according to the above as well. Although the principles of urban design principles can vary from one locality to another, there are some common points to be considered such as design for healthy environment, creating attractive public spaces, strengthening local identities, pedestrian access and other. The basic sustainability criteria and ecological principles are: use of the appropriate and preferably local construction material, energy efficiency, recycling, minimizing noise, maintaining comfort and harmony with nature, adaptation of local design styles walk able local transport system etc. In the end, the role of the legal authorities who are enabling the operation of the model at all stages is crucial for its success. It is important to clarify the roles of various stakeholders within the model. 
Fig. 4: The proposed spatial planning model for tourism development of Bosnia and Herzegovina at Municipality level

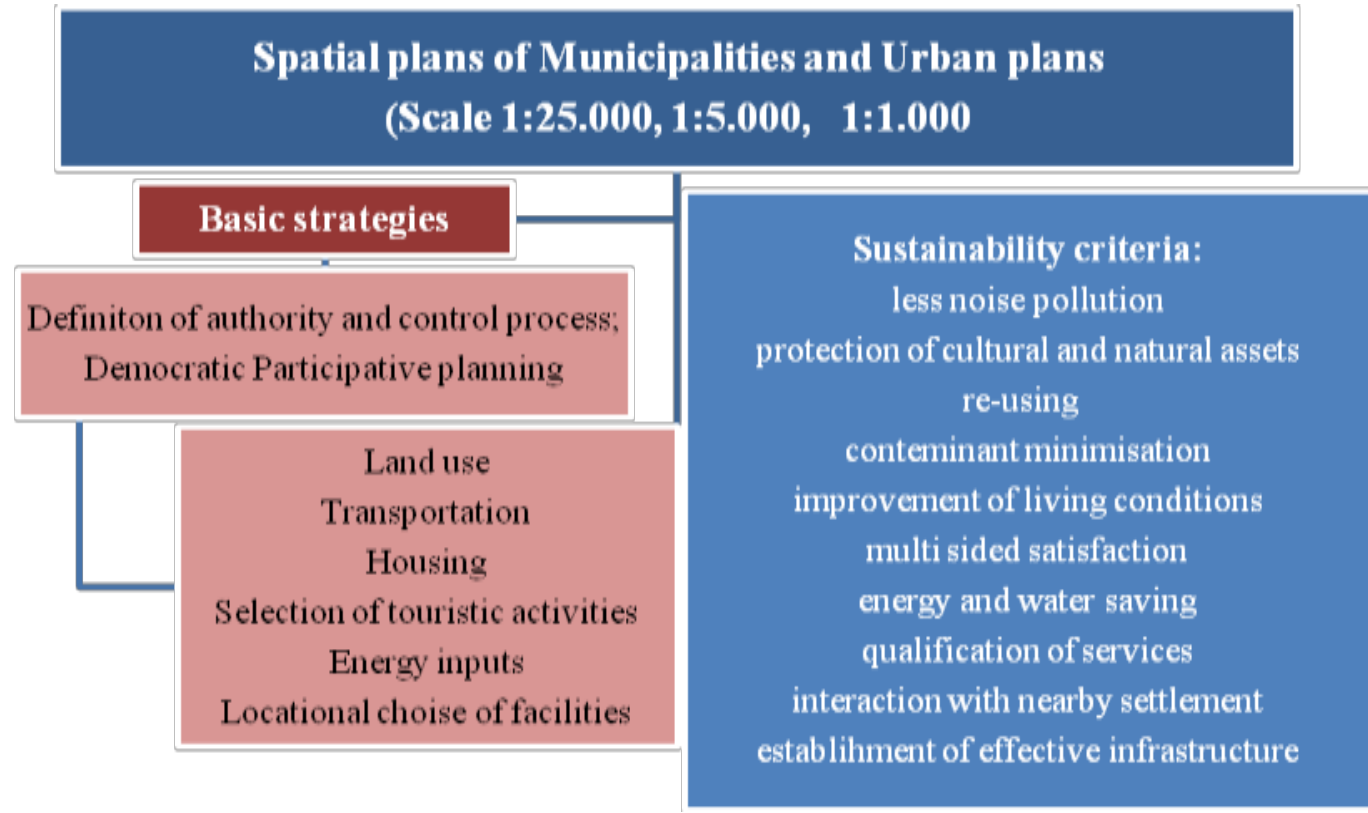

The organizational chart should include several institutions that are involved in different stages of the model. The first step is defining the stakeholders; the second one is defining the processes of planning from decision making stage to monitoring stage. Central and local authorities, sector institutions and stakeholders such as NGOs, entrepreneurs, members of the local communityand other play various roles in the proposed spatial planning process for the sustainable development of the tourism sector.

Fig. 5: The proposed spatial planning model for tourism development of Bosnia and Herzegovina through Regulatory, Zoning plans and Urban projects

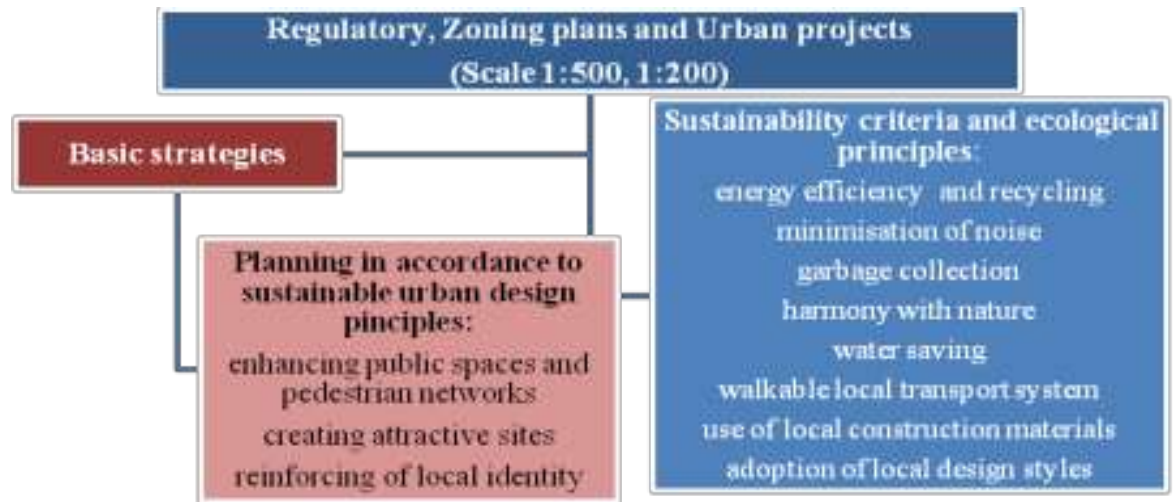

In Bosnia and Herzegovina, central authorities include Federal Ministry of Physical Planning (FMPU), Ministry of Spatial Planning, Civil Engineering and Ecology of 
Republic of Srpska, Federal Ministry of Environment and Tourism (FMOIT), Ministry of Trade and Tourism of Republic of Srpska, Federal Ministry of Culture and Sports (FMKS), Ministry of Family, Youth and Sports of Republic of Srpska, Federal Ministry of Education and Science (FMOK), Ministry of Education and Culture of Republic of Srpska, Federal Ministry of Transport and Communications, Ministry of Transport and Communications of Republic of Srpska, Federal Ministry of Agriculture, WaterManagement and Forestry, Ministry of Agriculture, Forestry and Waters of Republic of Srpska, Federal Ministry of Development, Entrepreneurship and Crafts, Ministry of Economic Relations and Regional Cooperation of Republic of Srpskaand other related ministries. Local authorities include municipalities, local communities and similar. Sectoral stakeholders include experts from universities, tourism unions, professional associations such as the Tourist Boards of all the Cantons in Federation of Bosnia and Herzegovina and Tourist Organization of Republic of Srpska, or associations of hotel owners, related chambers and unions as well as the Development Agencies or Investment Agencies. The planning process includes the stages of decision making, plan making, execution, supervision and monitoring. The role of stakeholders in the planning process is presented in Table2., as a part of theoretical model of spatial planning for sustainable tourism development.

Table 2:The roles of stakeholders in the proposed spatial planning model for sustainable tourism development in Bosnia and Herzegovina

\begin{tabular}{|c|c|c|c|c|c|}
\hline $\begin{array}{c}\text { Plan stages/ } \\
\text { actions }\end{array}$ & $\begin{array}{l}\text { Decision } \\
\text { making }\end{array}$ & Planning & Execution & $\begin{array}{c}\text { Supervisi } \\
\text { on }\end{array}$ & Monitoring \\
\hline $\begin{array}{l}\text { National/Entity } \\
\text { plans }\end{array}$ & $\begin{array}{l}\text { National/Entit } \\
\text { y authorities }\end{array}$ & $\begin{array}{c}\text { National/Entit } \\
\text { y authorities }\end{array}$ & $\begin{array}{c}\text { National/Ent } \\
\text { ity } \\
\text { authorities/ } \\
\text { Cantonal/ } \\
\text { Municipality } \\
\text { authorities }\end{array}$ & $\begin{array}{l}\text { All actors } \\
\text { except } \\
\text { represent } \\
\text { atives of } \\
\text { the local } \\
\text { communi } \\
\text { ty }\end{array}$ & All actors \\
\hline $\begin{array}{l}\text { Cantonal and/or } \\
\text { City plans }\end{array}$ & $\begin{array}{c}\text { National/Entit } \\
\text { y authorities/ } \\
\text { Cantonal/ } \\
\text { Municipality } \\
\text { authorities }\end{array}$ & $\begin{array}{l}\text { Cantonal/ } \\
\text { Municipality } \\
\text { authorities }\end{array}$ & $\begin{array}{l}\text { Cantonal/ } \\
\text { Municipality } \\
\text { authorities }\end{array}$ & All actors & All actors \\
\hline $\begin{array}{l}\text { Local/Municipali } \\
\text { ty development } \\
\text { plans }\end{array}$ & $\begin{array}{l}\text { Cantonal/ } \\
\text { Municipality } \\
\text { authorities }\end{array}$ & $\begin{array}{l}\text { Cantonal/ } \\
\text { Municipality } \\
\text { authorities }\end{array}$ & $\begin{array}{l}\text { Cantonal/ } \\
\text { Municipality } \\
\text { authorities }\end{array}$ & $\begin{array}{c}\text { Cantonal/ } \\
\text { Municipa } \\
\text { lity } \\
\text { authoritie } \\
\text { s, related } \\
\text { NGO's, } \\
\text { universiti } \\
\text { es, } \\
\text { represent } \\
\text { atives of }\end{array}$ & All actors \\
\hline
\end{tabular}




\begin{tabular}{|c|c|c|c|c|c|}
\hline & & & & $\begin{array}{c}\text { the local } \\
\text { communi } \\
\text { ty }\end{array}$ & \\
\hline Urban design & $\begin{array}{c}\text { Cantonal/ } \\
\text { Municipality } \\
\text { authorities/ } \\
\text { Entrepreneurs }\end{array}$ & $\begin{array}{c}\text { Cantonal/ } \\
\text { Municipality } \\
\text { authorities/ } \\
\text { Entrepreneurs }\end{array}$ & $\begin{array}{c}\text { Cantonal/ } \\
\text { Municipality } \\
\text { authorities/ } \\
\text { Entrepreneur } \\
\text { s }\end{array}$ & $\begin{array}{l}\text { Cantonal/ } \\
\text { Municipa } \\
\text { lity } \\
\text { authoritie } \\
\text { s, related } \\
\text { NGO's, } \\
\text { universiti } \\
\text { es, } \\
\text { represent } \\
\text { atives of } \\
\text { the local } \\
\text { communi } \\
\text { ty }\end{array}$ & $\begin{array}{c}\text { Cantonal/ } \\
\text { Municipality } \\
\text { authorities, } \\
\text { related } \\
\text { NGO's, } \\
\text { universities, } \\
\text { representativ } \\
\text { es of the } \\
\text { local } \\
\text { community }\end{array}$ \\
\hline
\end{tabular}

\section{DISCUSION AND CONCLUSION}

The main link in correlation of spatial planning and sustainable tourism is their common goal - to recognize and protect the values of natural-geographical and culturalhistorical heritage in order to enhance their development and to improve their management in the long term. The process of spatial planning which includes the principles of sustainable tourism requires motivation, determination and a systematic approach, as it should integrate the needs of authorities, stakeholders, local community, but also the needs of the environment and heritage. Sustainable tourism is a long-term goal. An adequate integration of sustainability criteria in the spatial and tourism planning process is an important part of the picture, as marketing, interpretation and creating a satisfying experience for the visitor depends of it. Spatial planning is an activity that requires an integrative and comprehensive planning approach in order to rationalize an appropriate land use activities, as a fragmented and partial spatial planning activities without a comprehensive viewpoint would harm local communities instead of making them benefit from tourism development. In this respect, spatial planning for sustainable tourism shouldbe applied in an organized and holistic way. Therefore, this paper presented a spatial planning model for the development of sustainable tourism in Bosnia and Herzegovina.At every planning stage in the model, it is easy to control sustainable development with the differentiated sustainability criteria at each level. An entire planning process can be applied from start to finish, or can be used in part if more appropriate. The proposed model represents only a rough picture of what is designed to be flexible and can be adapted, as it is applied to many and varied levels. Suggested sustainability criteria were listed as a proposition of activities which should of course be considered in more detail in actual planning process. Preparation or organization of the spatial planning model/ process depends on engagement of various 
professionals (geographers, economists, landscape designers, civil engineers etc.), so participation of all governmental and non-governmental as well as local community and, finally, monitoring and evaluation of all planning stages are crucial for the success of the plans.They all have particular ideas, issues and interests. If all groups are to benefit, the perspectives of these groups need to be considered in making decisions for the future. The model is designed to include and integrate the views of these different groups to achieve positive outcomes for all. Institutional and organizational structures could be considered as the key factors for the success of spatial planning for any kind of development. Hence, their identification is necessary for the successful operation of the model. An efficient operation of the model depends on legal aspects that support sustainable development of the tourism sector. On the other hand, spatial planning model for sustainable development may help to build a productive and lasting partnership between natural-geographical and cultural-historical heritage and tourism in Bosnia and Herzegovina.

\section{REFERENCES}

1. Björk, P. (2000). Ecotourism from a Conceptual perspective, An Extended Definition of a Unique Tourism Form. International Journal of Tourism Research, (2), 189-202.

2. Bublin, M. (2000)Prostornoplaniranje, Sarajevo: Univerzitetskaknjiga

3. Diamantis, D. (1999). The Concept of Ecotourism: Evolution and Trends. Current Issues in Tourism, 2(2), 93-122.

4. Dredge, D., Moore, S. (1992). A Methodology for the Integration of Tourism in Town Planning. The Journal of Tourism Studies, 3(1), 8-21.

5. European Commission. (1997). The EU Compendium of Spatial Planning Systems and Policies. EU Regional Development Studies Series (28).Retrieved from http://www.espace-project.org/publications/EUcompendium.pdf.

6. Federalnoministarstvoprostornoguređenja (2012).Prostorni plan FederacijeBosneiHercegovineza period 2008-2028. godine, Sarajevo

7. Gunn, C.A. (1988). Tourism Planning ( $2^{\text {nd }}$ Ed.). New York: Taylor and Francis.

8. Hall, C.M. (2008). Tourism Planning: Policies, Processes and Relationships $\left(2^{\text {nd }}\right.$ Ed.).Essex:Pearson Education

9. Hunter, C. (1997): Sustainable tourism as an adaptive paradigm, Annals of Tourism Research, (24), 850-67.

10. Korjenić, A. (2015). Spatial planning in Bosnia and Herzegovina - Legislative framework, ActageographicaBosniaeetHerzegovinae, Udruženjegeografa u BosniiHercegovini, (3), 53-62.

11. Maksin-Mičić M. (2008).Turizamiprostor, Beograd: UniverzitetSingidunum

12. Marinović-Uzelac A. (2001). Prostornoplaniranje, Zagreb:Dom isvijet.

13. Mason, P. (2003) Tourism Impacts, Planning and Management, Oxford: Butterworth-Heinemann. 
14. McLennan, J. F. (2004). The Philosophy of Sustainable Design, Kansas: Ecotone Publishing Company LLC

15. Mill, R.C., Morrision A.M. (2002). The Tourism System, Dubuque: Kendal/Hunt

16. Perišić D. (1985). O prostornomplaniranju,Beograd: InstitutzaarhitekturuiurbanizamSrbije

17. U.K. Department for Communities and Local Government (2009). Good Practice Guide on Planning for Tourism.Retrieved from

18. http://www.communities.gov.uk/documents/planningandbuilding/pdf/151753.pdf

19. United Nations World Tourism Organization (2016). Agenda 21 for Travel and Tourism Industry.Retrieved from http://www.worldtourism.org/sustainable/doc/a21-cover.pdf

20. United Nations. (2008). Spatial Planning: Key Instrument for Development and Effective Governance with Special Reference to Countries in Transition, Economic Commission for Europe. Retrieved from www.unece.org/hlm/documents/Publications/spatial planning.e.pdf

21. United Nations Environment Program (2009). Making Tourism More Sustainable: A Guide for Policy Makers, Retrieved from http://www.unep.fr/shared/publications/pdf/DTIx0592xPA-TourismPolicyEN.pdf

22. UrbanističkizavodRepublikeSrpske (2015). Prostorni plan RepublikeSrpske do 2025. godine, Retrieved from: www.vladars.net/sr-SPCyrl/Vlada/Ministarstva/mgr/Documents/ 